\title{
PENGEMBANGAN MODUL PEMBELAJARAN PENDIDIKAN AGAMA ISLAM DAN BUDI PEKERTI BERBASIS CONTEXTUAL TEACHING AND LEARNING (CTL) PADA MATERI PENYELENGGARAAN JENAZAH DI SMK NEGERI 1 BATIPUH
}

\author{
Nicha Andri Yani ${ }^{1}$, Masrili ${ }^{2}$, Ridwal Trisoni ${ }^{3}$ \\ ${ }^{1}$ Guru SMK Negeri 1 Batipuh, 2,3IAIN Batusangkar \\ e-mail: nichaandriyani@gmail.com, masril@iainbatusangkar.ac.id, \\ ridwaltrisoni@iainbatusangkar.ac.id
}

\begin{abstract}
The problem of this research is the limitation of learning resource on Islamic Education and Character. In the learning process, the teacher only has book package of Islamic Education and character without presenting module, handout, LKS and other materials. The general purpose of this research is to find a module of Islamic education and character based on Contextual Teaching and Learning (CTL). Meanwhile, the specific purpose is to createthe valid and practical modules of Islamic education and character based on Contextual Teaching and Learning (CTL) so that it can be used by teacher and students in the school as a guiding in the learning process. The type of this research is developing research and also using 4-D models. It has 4 stages, they are define, design, developdan disseminate. The result of this research shows theeverage is 86 $\%$ from validity of module Islamic Education and Character based on Contextual Teaching and Learning (CTL) with very valid category.Meanwhile, the result of practicality from development of module islamic education and chacter based on Contextual Teaching and Learning (CTL) on material of organizing the corpse are obtained $90 \%$ with very practical category.Based on the description above, it can be concluded that the development of PAI \& BP Modules based on Contextual Teaching and Learning (CTL) on the material of organizing the corpse can be declared it is very valid and very practical so that it is suitable using for all teachers of Islamic Education and Character in the school.
\end{abstract}

Keyword: Contextual Teaching and Learning, Islamic Education, high School. Batipuh

\section{PENDAHULUAN}

Dalam proses pembelajaran Pendidikan Agama Islam dan Budi Pekerti kelas XI di SMK Negeri 1 Batipuh terdapat permasalahan yang berkaitan dengan keterbatasan sumber belajar Pendidikan Agama Islam dan Budi Pekerti.

Sumber belajar merupakan segala sesuatu yang dapat dimanfaatkan 
untuk belajar dan dapat memberikan kemudahan bagi seseorang dalam kegiatan belajarnya. Agustina (2014: 71) mendefinisikan sumber belajar dirumuskan sebagai segala sesuatu yang dapat memberikan kemudahan kemudahan kepada peserta didik dalam memperoleh sejumlah pengetahuan, pengalaman, dan keterampilan dalam proses belajar mengajar.

Sitepu (2014: 18) dalam Dictionary of instructonal Technology (1986) yang menyebutkan sumber belajar adalah "Any resources (people, Intructional material, Intructional hardware,etc) which may be usesd by a learner to bring about or facilitate learning". Rumusan itu menunjukkan sumber belajar mencakup apa saja, termasuk orang, bahan pembelajaran, perangkat keras pembelajaran dan lain-lain yang dapat dipergunakan oleh pembelajar untuk memudahkannya belajar.

Mulyasa (2009: 177) mengatakan bahwa manfaat dari sumber belajar bergantung pada kemauan dan kemampuan guru dan peserta didik untuk berkomunikasi dan berinteraksi dengan pesan-pesan yang terkandung dalam sumber belajar yang didayagunakan. Dari berbagai sumber belajar yang ada dapat dikelompokkan sebagai berikut: 1) Manusia 2) Bahan 3) Lingkungan, 4) Alat dan peralatan 5) Aktivitas
Dari beberapa sumber belajar di atas, guru bisa mendayagunakan sumber belajar yang ada, salah satunya berupa bahan. Dimana guru mampu mengembangkan bahan ajar yang dapat membantu tercapainya tujuan pembelajaran. Karena dengan adanya bahan ajar ini akan memudahkan guru menyampaikan materi kepada peserta didik.

Salah satu bentuk bahan ajar atau materi ajar yaitu dalam bentuk modul pembelajaran. Walter Dick dan Lou Carey dalam (Nurdin, 2016: 272) bahwa modul diartikan sebagai unit pembelajaran berbentuk cetak, mengajar terpadu yang memiliki satu tema terpadu, menyajikan kepada siswa keterangan-keterangan yang diperlukan untuk menguasai dan menilai pengetahuan dan keterampilan yang ditentukan dan berfungsi sebagai satu komponen dan keseluruhan kurikulum.

Keunggulan dari modul juga ditemukan pada penelitian yang dilakukan oleh Anafidah, dkk. (2017, p. 29-39) dengan judul Pengembangan Modul Fisika Berbasis Contextual Teaching and Learning (CTL) pada Materi dinamika Partikel untuk meningkatkan Keterampilan berpikir Kritis Siswa Kelas X SMAN 1 Ngawi. Hasil penelitian menunjukkan bahwa: "Tingkat keterampilan berpikir kritis siswa mengalami peningkatan setelah mengikuti proses 
pembelajaran menggunakan modul Fisika Berbasis Contextual Teaching and Learning (CTL) pada Materi dinamika Partikel. Hal ini dapat menunjukkan dengan hasil perbandingan nilai preetest dan postest dengan $\mathrm{N}$-gain sebesar 0.36 . $\mathrm{N}$-gain menunjukkan modul Fisika Berbasis Contextual Teaching and Learning (CTL) pada Materi dinamika Partikel dengan kategori sedang."

(Hasil wawancara peneliti dengan guru Pendidikan Agama Islam dan Budi Pekerti, Bapak Mukhtar, Selasa, 22 Januari 2019) bahwa dalam proses pembelajaran guru hanya memiliki buku paket Pendidikan Agama Islam dan Budi Pekerti tanpa adanya bahan ajar lain berupa modul, handout, LKS dan lainnya. Materi yang tersaji dalam buku tersebut sangat sangat sulit siswa untuk memahaminya, dan guru juga sulit mengembangkan bahan ajar berupa modul Pendidikan Agama Islam dan Budi Pekerti berbasis Contextual Teaching and Learning (CTL).

Contextual Teaching And Learning (CTL) merupakan suatu strategi pembelajaran yang menekankan kepada proses keterlibatan siswa secara penuh untuk dapat menemukan materi yang sedang dipelajari dan mengaitkannya dengan kehidupan sehari-hari. Menurut Hudson (Vol.6:

4) menyatakan bahwa:

"Contextual teaching and learning is a conception of teaching and learning that helps teachers relate subject matter content to real world situations; and motivates students to make connections between knowledge and its applications to their lives as family members, citizens, and workers; and engage in the hard work that learning requires."

Pendekatan contextual ini, siswa dianggap sebagai subjek belajar yang dapat berperan secara aktif dalam proses pembelajaran untuk mengkonstruksi pengetahuannya sendiri. Menurut Depdiknas dalam (Nurdin, 2016: 206), ada tujuh prinsip yang mendasari pendekatan kontekstual, yaitu: Pertama: kontruktivisme (contructivisme), kedua: bertanya (Questioning), ketiga: menemukan (inquiry), keempat: masyarakat belajar (learning comunity), kelima: pemodelan (modelling), keenam: refleksi (reflection), ketujuh: penlaian sebenarnya (Authentic Assesment).

Secara filosofis, CTL banyak dipengaruhi oleh filsafat kontruktivisme yang mulai digagas oleh Mark Baldwin dan selanjutnya dikembangkan oleh Jean Piaget. Sejak kecil setiap anak sudah memiliki struktur kognitif yang kemudian dinamakan "skema". Skema terbentuk karena pengalaman, dan proses penyem- 
purnaan skema itu dinamakan asimilasi dan semakin besar pertumbuhan anak maka akan semakin sempurna yang kemudian disebut dengan proses akomodasi (Nurdin, 2016: 200). Filosofis menekankan bahwa belajar tidak hanya sekedar menghafal. Siswa harus mengkonstruksikan pengetahuan dibenak mereka sendiri. Bahwa pengetahuan tidak dapat dipisah-pisahkan menjadi fakta.

Di dalam modul berbasis Contextual Teaching And Learning (CTL) siswa tidak hanya menghafal, mengingat pengetahuan tetapi merupakan suatu proses belajar mengajar dimana siswa sendiri aktif membangun penetahuannya (kontruktivisme), lalu pengetahuan yang dimiliki seseorang selalu dimulai dari bertanya, menemukan suatu konsep dengan merumuskan masalah, melakukan observasi, menganalisis serta menyajikan hasil karyanya. Setelah itu masyarakat belajar yang menyarankan hasil pembelajaran itu diperoleh dari hasil kerja sama dari orang lain. Kemudian dilanjutkan pada tahap pemodelan dan yang terakhir refleksi. Berdasarkan tahapan Contextual Teaching And Learning (CTL) diatas, dapat membantu siswa secara penuh baik fisik maupun mental dalam menemukan suatu konsep yang kemudian dihubungkan dengan konteks kehidupan nyata dan mendorong siswa untuk menerapkannya dalam kehidupan seharihari.

\section{LANDASAN TEORITIS}

\section{Modul}

Secara bahasa, kata modul diambil dari Bahasa Inggris "module" yang berarti "unit, bagian, atau juga bermakna kursus, latihan, pelajaran berupa kursus yang besar". Dalam kamus Bahasa Indonesia modul berarti "unit usaha kecil dari satu pelajaran yang dapat beroperasi sendiri". Jadi modul bermakna kumpulan satu unit program belajar mengajar terkecil yang terinci yang terdapat pada komponen-komponen modul. (Ramayulis, 2012: 183)

Dalam mengembangkan sebuah modul pembelajaran harus diperhatikan komponen-komponen yang menyusunnya. Komponen-komponen tersebut adalah Pedoman Guru, Lembar Kegiatan Siswa, Lembar Kerja Siswa, Kunci Jawaban untuk Lembaran Kerja Siswa, Lembaran Soal, Kunci jawaban yang berisi jawaban yang benar setiap soal yang ada dalam lembar penilaian yang digunakan sebagai alat koreksi sendiri terhadap pekerjaan yang telah dilakukan. (Syarifuddin, 2007: 221-223) 
Model Pembelajaran Contextual Teaching And Learning (CTL)

Pembelajaran Contextual Teaching and Learning (CTL) merupakan konsep belajar yang membantu guru mengaitkan antara materi yang diajarkannya dan situasi dunia nyata pembelajar dan mendorong pembelajar membuat hubungan antara pengetahuan yang dimilikinya dan penerapannya dalam kehidupan mereka sebagai anggota keluarga dan masyarakat, serta pengetahuan yang diperoleh dari usaha peserta didik mengontruksikan sendiri pengetahuan dan keterampilan baru ketika ia belajar (Saefuddin, dkk: 2015).

Pendekatan kontekstual adalah sebuah pembelajaran yang terfokus dalam melibatkan siswa aktif memperoleh informasi yang dilaksanakan dengan mengenalkan mereka pada lingkungan serta terlibat secara langsung dalam proses pembelajarannya.

"Contextual teaching and learning (CTL) is a concept that helps teachers relate subject matter to real word situations. CTL motivates leaners to take charge of their own learning and to make connections between knowledge and its applications to the various contexts of their lives: as family members, as citizens, and as workers. It provides a conceptual framework for unifying a constellatin of education theories and practices and represents one approach to improving teacher education. Sears (2003: 7)"

Pendekatan contextual ini, siswa dianggap sebagai subjek belajar yang dapat berperan secara aktif dalam proses pembelajaran untuk mengkonstruksi pengetahuannya sendiri. Menurut Depdiknas dalam (Nurdin, 2016: 206), ada tujuh prinsip yang mendasari pendekatan kontekstual, yaitu: Pertama: kontruktivisme (contructivisme), kedua: bertanya (Questioning), ketiga: menemukan (inquiry), keempat: masyarakat belajar (learning comunity), kelima: pemodelan (modelling), keenam: refleksi (reflection), ketujuh: penlaian sebenarnya (Authentic Assesment).

\section{Pendidikan Agama Islam dan Budi Pekerti}

Pendidikan Agama Islam dan Budi Pekerti adalah usaha sadar untuk menyiapkan siswa dalam meyakini,memahami, menghayati dan mengamalkan agama Islam melalui kegiatan bimbingan, pengarahan atau latihan dengan memerhatikan tuntunan untuk menghormati agama lain dalam hubungan kerukunan antar umat beragama dalam bermasyarakat untuk mewujudkan kesatuan nasional (Hawi, 2013: 19 ). Jadi pendidikan agama Islam dan Budi Pekerti merupakan usaha sadar yang dilakukan pendidik dalam rangka mempersiapkan peserta didik untuk meyakini, 
memahami, dan mengamalkan ajaran Islam melalui kegiatan bimbingan, pengajaran atas pelatihan yang telah ditentukan untuk mencapai tujuan yang telah di tetapkan.

\section{METODE PENELITIAN}

Penelitian ini termasuk penelitian dan pengembangan. Metode penelitian dan pengembangan atau Research and Development adalah metode penelitian yang digunakan untuk menghasilkan produk tertentu, dan menguji keefektifan produk tersebut (Sugiyono, 2012: 407).

Dalam penelitian ini, model penelitian pengembangan yang digunakan adalah model 4-D (Four D model). Model pengembangan 4-D terdiri atas empat tahap pengembangan, yaitu define, design, develop dan disseminate (Trianto, 2009: 189). Namun untuk menghemat waktu, biaya dan tenaga rancangan penelitian yang akan dilakukan pada penelitian ini terdiri dari tiga tahap, yaitu "Define, Design, Develop". Tahap Disseminate pada penelitian ini tidak dilakukan tanpa mengurangi arti penelitian ini, maka tahap yang digunakan hanya sampai tahap Develop"

Berikut penjelasan model penelitian dan pengembangan yang telah dilaksanakan:

\section{Tahap Define (Pendefenisian)}

Tahap ini bertujuan untuk menemukan dan mengumpulkan seluruh bahan-bahan yang terkait dengan materi penyelenggaraan jenazah yang akan dibuat menjadi modul pembelajaran pendidikan Agama Islam dan Budi Pekerti berbasis Contextual Teaching And Learning (CTL).

\section{Tahap Design (Perancangan)}

Tahap Design bertujuan untuk merancang prototipe modul pembelajaran pendidikan Agama Islam dan Budi Pekerti berbasis Contextual Teaching And Learning (CTL).

\section{Tahap Pengembangan (Develop)}

Tujuan tahap ini adalah untuk menghasilkan perangkat pembelajaran yang sudah direvisi berdasarkan masukan dari pakar dan mengetahui tingkat kepraktisan modul pembelajaran pendidikan Agama Islam dan Budi Pekerti berbasis Contextual Teaching And Learning (CTL). Tahap ini dilakukan dengan langkah-langkah uji validitas, dan uji praktikalitas.

Tahap ini dilakukan penilaian terhadap produk yang dibuat, penilaian tersebut dilakukan oleh 3 orang dosen dan 1 orang guru Pendidikan Agama Isma dan Budi Pekerti di sekolah SMK Negeri 1 Batipuh. Kriteria pemilihan 
validator berdasarkan masukan pembimbing dengan mempertimbangkan keahlian validator pada biadang keahliannya, yang terdiri dari 1 orang dosen ahli materi PAI dan 2 orang dosen ahli pendidikan. Selain itu, juga diminta kepada guru PAI SMK, agar modul yang dikembangkan sesuai dengan pembelajaran PAI di SMK N 1 Batipuh. Aspek-aspek validasi yang akan divalidasikan dapat dilihat pada tabel berikut:

Table. 1. Aspek validasi modul PAI berbasis Contekstual Teaching And Learning materi penyelenggaraan jenazah

\begin{tabular}{|c|c|c|c|c|}
\hline No & Aspek & Indikator & $\begin{array}{c}\text { Metode } \\
\text { Pengumpul } \\
\text { an Data }\end{array}$ & Instrumen \\
\hline 1 & $\begin{array}{l}\text { Aspek } \\
\text { kelayakan } \\
\text { isi }\end{array}$ & $\begin{array}{l}\text { a. Kesesuaian materi } \\
\text { dengan KI dan KD } \\
\text { b. Keakuratan materi } \\
\text { c. Mendorong } \\
\text { keingin tahuan } \\
\text { a. Kesesuaian dengan } \\
\text { perkembangan } \\
\text { peserta didik }\end{array}$ & \multirow{4}{*}{$\begin{array}{l}\text { Diskusi } \\
\text { dengan } \\
\text { pakar }\end{array}$} & \multirow{4}{*}{$\begin{array}{l}\text { Lembar } \\
\text { Validitas }\end{array}$} \\
\hline 2 & $\begin{array}{l}\text { Aspek } \\
\text { kelayakan } \\
\text { penyajian }\end{array}$ & $\begin{array}{l}\text { a. Teknik penyajian } \\
\text { b. Pendukung } \\
\text { penyajian } \\
\text { c. Penyajian } \\
\text { pembelajaran }\end{array}$ & & \\
\hline 3 & $\begin{array}{l}\text { Aspek } \\
\text { penilaian } \\
\text { CTL }\end{array}$ & $\begin{array}{l}\text { a. Hakikat CTL } \\
\text { b. Komponen CTL }\end{array}$ & & \\
\hline 4 & $\begin{array}{l}\text { Aspek } \\
\text { kelayakan } \\
\text { bahasa }\end{array}$ & $\begin{array}{l}\text { b. Sederhana } \\
\text { c. Dialogis dan } \\
\text { interaktif } \\
\text { d. Kesesuain dengan } \\
\text { kaidah bahasa }\end{array}$ & & \\
\hline
\end{tabular}

Tabel 2. Validasi Angket Respon

\begin{tabular}{|l|l|l|l|}
\hline No & \multicolumn{1}{|c|}{ Aspek } & \multicolumn{1}{|c|}{$\begin{array}{l}\text { Metode } \\
\text { Pengumpulan Data }\end{array}$} & Instrumen \\
\hline 1. & Format angket & $\begin{array}{l}\text { Diskusi dengan } \\
\text { validator dan pakar }\end{array}$ & $\begin{array}{l}\text { Lembar } \\
\text { validasi }\end{array}$ \\
\cline { 1 - 2 } 2. & $\begin{array}{l}\text { Bahasa yang } \\
\text { digunakan }\end{array}$ & \\
\cline { 1 - 2 } 3. & $\begin{array}{l}\text { Butir pertanyaan } \\
\text { angket }\end{array}$ & \\
\hline
\end{tabular}


Tabel 3. Aspek Praktikalitas Modul Pembelajaran Pendidikan Agama Islam

Berbasis Contekstual Teaching And Learning (CTL)

\begin{tabular}{|c|c|c|c|}
\hline No & Aspek & $\begin{array}{c}\text { Metode } \\
\text { Pengumpulan Data }\end{array}$ & Instrumen \\
\hline 1. & $\begin{array}{l}\text { Pelaksanaan } \\
\text { pembelajaran } \\
\text { dengan modul PAI } \\
\text { berbasis CTL }\end{array}$ & \multirow{4}{*}{$\begin{array}{c}\text { Pengisian angket oleh } \\
\text { siswa }\end{array}$} & \multirow{4}{*}{$\begin{array}{l}\text { Angket } \\
\text { respon } \\
\text { siswa }\end{array}$} \\
\hline 2. & $\begin{array}{l}\text { Bentuk modul PAI } \\
\text { berbasis CTL }\end{array}$ & & \\
\hline 3. & $\begin{array}{l}\text { Isi modul PAI } \\
\text { berbasis CTL }\end{array}$ & & \\
\hline 4. & $\begin{array}{l}\text { Kepraktisan modul } \\
\text { PAI berbasis CTL }\end{array}$ & & \\
\hline
\end{tabular}

4. Tahap (Disseminate)

Tahap ini merupakan tahap penggunaan perangkat yang telah dikembangkan pada skala yang lebih luas, misalnya di kelas lain, di sekolah lain, oleh guru yang lain. Tujuan lain adalah untuk menguji efektivitas penggunaan perangkat di dalam KBM (Trianto, 2011, p. 93)

Pada penelitian ini tahap disseminate tidak dilakukan,maka tahap yang digunakan hanya sampai tahap develop, hal ini dikarenakan keterbatasan waktu dan dana yang minim yang peneliti miliki.

Teknik analisis data yang digunakan penelitian ini Teknik analisis data yang digunakan adalah sebagai berikut:

\section{Analisis Validitas}

Analisis validitas dilakukan dengan cara menganalisis seluruh aspek yang dinilai oleh masing-masing validator terhadap modul yang dikembangkan. Analisis dilakukan dalam bentuk tabel, agar dapat mengetahui presentase kevalidan, dengan menggunakan rumus:

$$
\begin{aligned}
& \text { Nilai validitas = } \\
& \frac{\text { skor total seluruh aspek }}{\text { skor maksimal seluruh aspek }} \text { × } 100 \% \\
& \text { Untuk menentukan tingkat } \\
& \text { kevalidan modul digunakan } \\
& \text { kriteria seperti tabel dibawah ini, : } \\
& \text { (Riduwan, 2005.p. 89) }
\end{aligned}
$$

\section{Tabel 4. Persentase tingkat Validitas Lembar Validasi}




\begin{tabular}{|c|c|}
\hline Persentase Pencapaian & Interpretasi \\
\hline $\mathbf{8 1} \%-\mathbf{1 0 0} \%$ & Sangat Valid \\
\hline $61 \%-80 \%$ & Valid \\
\hline $41 \%-60 \%$ & Cukup Valid \\
\hline $21 \%-40 \%$ & Kurang Valid \\
\hline $0 \%-20 \%$ & Tidak Valid \\
\hline
\end{tabular}

\section{Analisis Praktikalitas}

Data angket diperoleh dengan cara menghitung skor siswa yang menjawab masingmasing item sebagaimana terdapat pada angket. Hasil yang diperoleh diinterpretasikan dengan menggunakan criteria berikut: (Riduwan, 2005.p. 89)

Hasil diperoleh diinterpretasikan dengan menggunakan kriteria berikut:

Tabel 5. Kategori Praktikalitas Modul Berbasis Contextual

Teaching And Learning (CTL)

\begin{tabular}{|l|l|c|}
\hline No. & Kriteria & Range Persentase (\%) \\
\hline 1. & Tidak praktis & $0-20$ \\
2. & Kurang praktis & $21-40$ \\
3. & Cukup praktis & $41-60$ \\
4. & Praktis & $61-80$ \\
5. & Sangat praktis & $81-100$ \\
\hline
\end{tabular}

HASIL PENELITIAN DAN

\section{PEMBAHASAN}

Berdasarkan penelitian

pengembangan yang telah dilakukan

di lapangan bahwa pengembangan

modul pembelajaran Pendidikan

Agama Islam dan Budi Pekerti

berbasis Contextual Teaching and

Learning (CTL) ini adalah model

pengembangan 4-D. Proses

pengembangan meliputi empat tahap yang dijelaskan berdasarkan model pengembangan yang akan digunakan, Tahap-tahap tersebut meliputi tahap pendefenisian (define), tahap perancangan (design), tahap pengembangan (develop) dan tahap penyebaran (disseminate). Masingmasing tahap pengembangan tersebut dijelaskan sebagai berikut:

\section{Analisis Define (Pendefenisian)}


Pada

tahap

(Pendefinisian)

dilakuka

silabus, analisis buku paket, analisis

karakteristik

peserta

didik.

Berdasarkan hasil analisis silabus

mata pelajaran Pendidikan Agama

Islam dan Budi Pekerti kelas XI semester ganjil diperoleh hasil bahwa silabus yang digunakan berdasarkan kurikulum 2013. Materi yang dikembangkan dalam modul

Contextual Teaching and Learning (CTL) adalah pada materi penyelenggaraan jenazah. Alasan penulis memilih Materi Pokok dan KD tersebut adalah karena Materi Pokok dan KD ini sesuai dengan basis yang penulis kembangkan dalam pembuatan modul yaitu Contextual Teaching and Learning (CTL).

Hasil analisis buku paket Pendidikan Agama Islam dan Budi Pekerti kelas XI di SMK N 1 Batipuh. Jumlah buku ajar yang digunakan dalam proses belajar mengajar sangatlah terbatas, guru hanya memiliki satu buku paket kurikulum 2013, yang mana buku paket yang digunakan guru sama dengan buku pegangan siswa. materi yang tersaji dalam buku sulit bagi siswa untuk memahami dan menggali informasi tentang materi yang sedang dipelajari.

Analisis peserta didik dilakukan bertujuan untuk memberikan solusi terhadap permasalahan yang dijumpai peserta didik dalam pembelajaran dan mengimpuun data tentang faktor-faktor pendukung dan penghambat dalam pembelajaran. Analisis yang dilakukan berupa wawancara dengan guru bidang studi Pendidikan Agama Islam dan beberapa orang peserta didik. Hasil analisis yang dilakukan pada siswa kelas XI SMK Negeri 1 Batipuh menunjukkan bahwa dalam proses pembelajaran terdapat kecenderungan siswa yang hanya mempelajari bku teks tanpa ada bahan jar lain (Modul, LKS), siswa hanya menghafal konsep maupun teori yang terdapat pada buku. Siswa lebih bersifat pasif, karena proses pembelajaran masih berpusat pada guru, mendengarkan ceramah dari guru dan mencatat materi yang disampaikan.

\section{Tahap Design (Perancangan)}

Tahap perancangan (Design) dilakukan setelah tahap define modul untuk pembelajaran Pendidikan Agama Islam dan Budi Pekerti pada materi penyelenggaraan jenazah. Kompetensi Dasar untuk materi ini adalah menganalisis pelaksanaan penyelenggaraan jenazah dan mempraktikkan prosedur penyelenggraan jenazah. Berikut diuraikan modul berbasis modul berbasis Contextual Teaching and Learning (CTL) pada materi penyelenggaraan jenazah di SMK 
Negeri 1 Batipuh yang telah di rancang.

\section{Tahap Pengembangan (Develop)}

Sebelum analisis Develop (Pengembangan) dilakukan. Produk modul pembelajaran pendidikan Agama Islam dan Budi Pekerti berbasis Contextual Teaching and Learning (CTL) telah selesai didiskusikan dengan pembimbing.

\section{a. Analisis Validitas}

Menurut Arikunto, 1995 dalam Riduwan menjelaskan bahwa validitas adalah suatu ukuran yang menunjukkan tingkat keandalan atau kesahihan suatu alat ukuran (Riduwan, 2005, p. 97). Selanjutnya, sugiyono mengatakan bahwa instrumen dikatakan valid bila instrument tersebut dapat digunakan untuk mengukur apa yang seharusnya diukur (Sugiyono, 2013, p. 173)
Modul yang telah dirancang dan didiskusikan dengan pembimbing selanjutnya divalidasikan oleh 1 orang dosen ahli Fikih, 2 orang dosen ahli Kependidikan dan 1 orang guru Pendidikan Agama Islam dan Budi pekerti, jadi terdiri dari 4 orang validator. Berikut diuraikan hasil validasi.

1) Hasil validitas modul Pendidikan Agama Islam berbasis Contextual Teaching and Learning (CTL) pada materi penyelenggaraan jenazah.

Data hasil pengolahan validasi modul Pendidikan Agama Islam berbasis Contextual Teaching and Learning (CTL) materi penyelenggaraan jenazah dari validator dituliskan pada tabel. Berikut:

Tabel 6. Hasil Analisis Validasi Modol Pendidikan Agama Islam dan Budi Pekerti berbasis Contextual Teaching and Learning (CTL) materi penyelenggaraan jenazah

\begin{tabular}{|c|c|c|c|c|c|c|c|c|c|}
\hline \multirow{2}{*}{$\begin{array}{l}\mathbf{N} \\
\mathbf{o}\end{array}$} & \multirow{2}{*}{$\begin{array}{c}\text { Aspek } \\
\text { Yang } \\
\text { Divalidasi }\end{array}$} & \multicolumn{4}{|c|}{ Validator } & \multirow{2}{*}{ Jml } & \multirow{2}{*}{$\begin{array}{l}\text { Skor } \\
\text { Mak } \\
\text { s }\end{array}$} & \multirow{2}{*}{$\%$} & \multirow{2}{*}{ Ket } \\
\hline & & 1 & 2 & 3 & 4 & & & & \\
\hline 1 & $\begin{array}{l}\text { Kelayakan } \\
\text { isi }\end{array}$ & 42 & 43 & 44 & 46 & 175 & 200 & $87 \%$ & $\begin{array}{l}\text { Sangat } \\
\text { Valid }\end{array}$ \\
\hline 2 & $\begin{array}{l}\text { Kelayakan } \\
\text { penyajian }\end{array}$ & 31 & 30 & 31 & 30 & 122 & 140 & $87 \%$ & $\begin{array}{l}\text { Sangat } \\
\text { Valid }\end{array}$ \\
\hline 3 & $\begin{array}{l}\text { Kelayakan } \\
\text { penilaian } \\
\text { CTL }\end{array}$ & 35 & 33 & 35 & 34 & 137 & 160 & $86 \%$ & $\begin{array}{l}\text { Sangat } \\
\text { Valid }\end{array}$ \\
\hline
\end{tabular}

\begin{tabular}{l|l} 
Pengembangan Modul Pendidikan Agama Islam dan Budi Pekerti... & 217
\end{tabular} 


\begin{tabular}{|c|c|c|c|c|c|c|c|c|c|}
\hline 4 & $\begin{array}{l}\text { Kelayakan } \\
\text { bahasa }\end{array}$ & 16 & 17 & 16 & 16 & 65 & 80 & $81 \%$ & $\begin{array}{l}\text { Sangat } \\
\text { Valid }\end{array}$ \\
\hline & Jumlah & 124 & 123 & 126 & 126 & 499 & 580 & $86 \%$ & $\begin{array}{l}\text { Sangat } \\
\text { Valid }\end{array}$ \\
\hline
\end{tabular}

Dari hasil validasi modul yang dinilai oleh 4 orang validator, seperti pada tabel 6 di atas, dapat diketahui rata-rata hasil validasi secara umum adalah 86\% dengan kategori sangat valid. Dari aspek-aspek yang dinilai didapat rata-rata nilai pada kelayakan isi $87 \%$, kelayakan penyajian $87 \%$, kelayakan penilaian Contextual Teaching and Learning (CTL) 86\%, kelayakan bahasa $81 \%$. Dapat disimpulkan bahwa modul Pendidikan Agama Islam berbasis Contextual Teaching and Learning (CTL) materi penyelenggaraan jenazah yang dikembangkan sudah valid dan dapat digunakan dalam proses pembelajaran. Pengakategorian hasil validitas modul Pendidikan Agama Islam berbasis Contextual Teaching and Learning

materi penyelenggaraan jenazah berdasarkan pendapat Riduwan dimana persentase antara 0\% - 20\% dengan kategori tidak valid, $21 \%-40 \%$ dengan kategori kurang valid, 41\%-60\% dengan kategori cukup valid, $61 \%-80 \%$ dengan kategori valid, dan 81\% $100 \%$ dengan kategori sangat valid.

2) Hasil Validitas rencana pelaksanaan pembelajaran (RPP) Pendidikan Agama Islam dan Budi Pekerti materi penyelenggaraan jenazah

Data hasil pengolahan validasi RPP Pendidikan Agama Islam \& Budi Pekerti berbasis Contextual Teaching and Learning (CTL) materi penyelenggaraan jenazah dari validator dituliskan pada tabel.7 berikut:

Tabel. 7. Hasil Validitas rencana pelaksanaan pembelajaran (RPP) Pendidikan Agama Islam dan Budi Pekerti materi penyelenggaraan jenazah

\begin{tabular}{|c|c|c|c|c|c|c|c|c|c|}
\hline \multirow{2}{*}{ No } & \multirow{2}{*}{$\begin{array}{l}\text { Aspek yang } \\
\text { divalidasi }\end{array}$} & \multicolumn{4}{|c|}{ validator } & \multirow{2}{*}{$\mathrm{Jml}$} & \multirow{2}{*}{$\begin{array}{l}\text { Skor } \\
\text { Maks }\end{array}$} & \multirow{2}{*}{$\%$} & \multirow{2}{*}{ Ket } \\
\hline & & 1 & 2 & 3 & 4 & & & & \\
\hline 1 & $\begin{array}{l}\text { Komponen } \\
\text { RPP }\end{array}$ & 42 & 49 & 50 & 191 & 191 & 224 & $85 \%$ & $\begin{array}{l}\text { Sangat } \\
\text { Valid }\end{array}$ \\
\hline 2 & $\begin{array}{l}\text { Prinsip } \\
\text { Penyusunan } \\
\text { RPP }\end{array}$ & 9 & 9 & 9 & 9 & 36 & 48 & $75 \%$ & Valid \\
\hline 3 & $\begin{array}{l}\text { Pelaksanaan } \\
\text { Pembelajaran }\end{array}$ & 39 & 43 & 43 & 45 & 170 & 208 & $82 \%$ & $\begin{array}{l}\text { Sangat } \\
\text { Valid }\end{array}$ \\
\hline
\end{tabular}




\begin{tabular}{|l|l|l|l|l|l|l|l|l|}
\hline JUMLAH & 90 & 101 & 102 & 245 & 397 & 480 & $83 \%$ & Valid \\
\hline
\end{tabular}

Dari hasil validasi RPP yang dinilai oleh 4 orang validator, seperti pada tabel 4.2 di atas, dapat diketahui ratarata hasil validasi secara umum adalah $83 \%$ dengan kategori sangat valid. Dari aspek-aspek yang dinilai didapt arat-rata nilai komponen RPP $85 \%$, prinsip penyusunan RPP 75\%, dan pelaksanaan pembelajaran $82 \%$. Dapat disimpulkan RPP Pendidikan Agama Islam dan Budi Pekerti berbasis Contextual Teaching and Learning (CTL) materi penyelenggaraan jenazah yang di rancang sudah valid dan dapat digunakan dalam dalam proses pembelajaran. Pengkategorian hasil validitas RPP Pendidikan Agama Islam dan Budi Pekerti berbasis Contextual Teaching and Learning (CTL) berdasarkan pendapat riduwan dimana presentase antara $0 \%-20 \%$ dengan kategori tidak valid, $21 \%$ $40 \%$ dengan kategori kurang valid, $41 \%-60 \%$ dengan kategori cukup valid, $61 \%-80 \%$ dengan kategori valid, dan $81 \%-100 \%$ dengan kategori sangat valid.

\section{b. Analisis Praktikalitas}

Untuk melihat praktikalitas modul Pendidikan Agama Islam \& Budi Pekerti berbasis Contextual Teaching and Learning (CTL) pada materi penyelenggaraan jenazah, dilakukan uji coba di SMK N 1 Batipuh kelas XI. Data tentang praktikalitas modul berbasis Cobtextual Teaching and Learning (CTL) untuk pembelajaran Pendidikan Agama Islam dan Budi Pekerti yang telah dirancang diperoleh dari lembar angket respons siswa. Berikut diuraikan hasil yang diperoleh mengenai praktikalitas modul berbasis Cobtextual Teaching and Learning (CTL) pada Pembelajaran Pendidikan Agama Islam dan Budi Pekerti.

Berdasarkan hasil analisis dari angket respons siswa di atas, maka dapat diketahui bahwa modul Pendidikan Agama Islam dan Budi Pekerti berbasis Contextual Teaching and Learning (CTL) pada materi penyelenggaraan jenazah di nilai sangat praktis dengan rata-rata 90\%. Pengkategorian hasil praktikalitas modul Pendidikan Agama Islam dan Budi Pekerti berbasis Contextual Teaching and Learning (CTL) pada materi penyelenggaraan jenazah berdasarkan pendapat Riduwan dimana presentase antara $0 \%-20 \%$ tidak praktis, $21 \%-40 \%$ kurang praktis, $41 \%-60 \%$ cukup praktis, 
$61 \%-80 \%$ praktis, $81 \%-100 \%$ sangat praktis.

Terkait dengan aspek kepraktisan, hasil penelitian Nieveen (1999) dalam Haviz (2013, p. 34), memperlihatkan cara mengukur tingkat kepraktisan. Hasil penelitian ini menjelaskan bahwa tingkat kepraktisan dilihat dari penjelasan apakah guru dan pakar lain memberikan pertimbangan bahwa materi mudah dan dapat digunakan oleh siswa. Nieveen juga menjelaskan produk hasil pengembangan, disimpulkan praktis jika (1) praktis menyatakan secara teoritis produk dapat diterapkan di lapangan dan (2) tingkat keterlaksanaan produk termasuk kategori baik.

Selain itu, menurut Akker (1999) dalam Fatmawati, (2016, p. 95), perangkat pembelajaran yang dikembangkan(yang dimaksud dengan perangkat pembelajaran yaitu bahan ajar), dimana bahan ajar tersebut salah satunya berupa modul. Pengembangan modul dikatakan berkualitas jika memenuhi tiga kriteria, yaitu validitas, kepraktisan, dan efektivitas.

\section{PENUTUP}

Kesimpulan
Berdasarkan

hasil pengembangan modul Pendidikan Agama Islam dan Budi Pekerti berbasis Contextual Teaching and Learning (CTL) materi penyelenggaraan jenazah dapat ditarik kesimpulan bahwa hasil pengembangan modul Pendidikan Agama Islam dan Budi Pekerti berbasis Contextual Teaching and Learning (CTL) materi penyelenggaraan jenazah terkategori sangat valid, setelah di nilai oleh validator dengan nilai rata-rata $86 \%$ dan hasil pengembangan modul Pendidikan Agama Islam dan Budi Pekerti berbasis Contextual Teaching and Learning (CTL) materi penyelenggaraan jenazah dinyatakan sangat praktis, dengan nilai rata-rata $90 \%$.

\section{Saran}

Berdasarkan hasil penelitian pengembangan Modul Pendidikan Agama Islam dan Budi Pekerti berbasis Contextual Teaching and Learning (CTL) materi penyelenggaraan jenazah di SMK Negeri 1 Batipuh disarankan kepada guru Pendidikan Agama Islam dan Budi Pekerti diharapkan untuk dapat menggunakan Modul Pendidikan Agama Islam dan Budi Pekerti berbasis Contextual Teaching and Learning (CTL) materi penyelenggaraan jenazah supaya 
dapat mengembangkan pengetahuan dan pemahaman siswa di dalam pembelajaran, Kepala SMK Negeri 1 Batipuh diharapkan untuk memfasilitasi pelaksanaan kegiatan yang ada dalam Modul Pendidikan Agama Islam dan Budi Pekerti berbasis Contextual Teaching and Learning (CTL) dan kepada siswa SMK Negeri 1 Batipuh khususnya kelas XI disarankan untuk menggunakan modul berbasis Contextual Teaching and Learning (CTL) pada pembelajaran Pendidikan Agama Islam dan Budi Pekerti agar interaksi dalam pembelajaran tidak satu arah, dan materi yang dipelajari mudah untuk dikuasai dan diterapkan dalam kehidupan sehari-hari.

\section{KEPUSTAKAAN ACUAN}

Agustina, D. 2014. Kompetensi Guru Dalam Pemanfaatan Sumber Belajar. Dalam jurnal ilmiah vol.2

Anafidah, A. Sarwanto \& Masykuri, M. 2017. Pengembangan Modul Fisika Berbasis Contextual Teaching and Learning (CTL) Pada Materi dinamika Partikel untuk meningkatkan Keterampilan Berpikir Kritis Siswa Kelas X SMAN 1 NGAWI. Jurnal Inkuiri, ISSN: 2252-7893, Vol. 6. No. 3
Fatmawati, A. (2016). Pengembangan

Perangkat Pembelajaran Konsep Pencemaran Lingkungan Menggunakan Model Pembelajaran Berdasarkan Masalah untuk SMA Kelas X: Jurnal Edu Sains, 4(2)

Haviz, M. (2013). Research and Development Penelitian di Bidang Kependidikan yang Inovatif Produktif dan Bermakna. Jurnal Ta'dib. 16(1): 28-43.

Hawi, A. 2013. Kompetensi Guru Pendidikan Agama Islam, Jakarta: Raja Wali Press

HUDSON, C. C. Contextual Teaching and Learning for Practitioners. Systemics, Cybernetics And Informatics, Vol. 6. ISSN: 16904524

Mulyasa, E. 2009. Kurikulum yang disempurnakan. Bandung: PT Remaja Rosdakarya

Nurdin, S. 2016. Kurikulum dan Pembelajaran. Jakarta: PT RajaGrafindo Persada

Ramayulis. 2012. Metodologi Pendidikan Agama Islam. Jakarta:Kalam Mulia

Riduwan. (2005). Belajar Mudah Penelitian untuk Guru, Karyawan, dan Peneliti Pemula,Bandung :Alfabeta

Saeuddin, H, S. and Berdiati, I. 2015. Pembelajaran Efektif. Bandung: PT Remaja Rosdakarya 
Sears, S, J. 2003. Introduction to Contextual Teaching and learning. Phi Delta Kappa Educational Foundation Bloomington Indiana

Setyosari, P. (2015). Metode Penelitian Pendidikan dan Pengembangan. Jakarta: Prenada media Group

Sitepu. 2014. Pengembangan Sumber Belajar. Jakarta: PT RajaGrafindo Persada

Sugiyono. 2013. Metode Penelitian Kuantitatif Kualitatif dan RED, Bandung: Alfabeta

Sugiyono.(2012). Metode Penelitian Pendidikan (Pendekatan Kuantitaif, Kualitatif, dan RED). Bandung: Alfabeta
Syarifuddin, dkk, 2007. Strategi Belajar Mengajar. Jakarta:Diaidit Media Trianto. (2009). Mendesain Model Pembelajaran Inovtif - Progresif Konsep, Landasan dan Implementasinya Pada Kurikulum Tingkat Satuan Pendidikan (KTSP) Jakarta :Kencana

Trianto. (2009). Mendesain Model Pembelajaran Inovtif - Progresif Konsep, Landasan dan Implementasinya Pada Kurikulum Tingkat Satuan Pendidikan (KTSP) Jakarta :Kencana

Trianto. 2011. Mendesain Pembelajaran Inovatif-Produktif. Kecana Prenada Media Grup. Jakarta 